\title{
THE HISTORY OF PSYCHIATRY IN LATVIA
}

We have the privilege to be alive at one of the turning points in history, when the nature of things has become unusually visible. The collapse of communism and the ultimate dissolution of the USSR, which resulted in the restoration of independence in Latvia, has confused many issues which had seemingly been settled.

In dealing with "Eastern psychiatry" over the last several decades, the West has focused almost entirely on the political abuse of psychiatry by totalitarian states and the professional and ethical standards used even when dealing with scientific or health care issues. Certainly Latvia was not an exception to these problems. However, if one wishes to understand the new, post-Soviet circumstances facing Latvian psychiatrists, and their future prospects, then one must research the distant and recent history of Latvian psychiatry as a whole. This paper deals mainly with the development of the health service system.

The development of psychiatry in Latvia was an integral part of the general development of psychiatry in Europe. Not only did it evolve into a scientific discipline with a firm grounding within general medicine, but it grew to encompass the social sciences and other humanities. Until the end of the 18th century, Baltic medicine paid little attention to mental patients and their illnesses, failing to consider this a separate branch of medicine. Special institutions for the care of such people had not yet been established. although it was possible for some Baltic physicians to receive an education at prominent European universities at least since the 14th century, and at a local university, Dorpat (Tartu), since 1632. Thus they were kept abreast of current classifications of diseases, which also included mental disorders. Riga city physicians gave their conclusions in the case of violent death[1]. In addition, there were numerous advances in the legal aspects of emerging psychiatry. For example, German legal standards developed in the city of Lübeck became widely accepted in the Baltic region. These standards eliminated the punitive legal aspects of suicide, which until then had been vigorously persecuted in Europe as a serious $\sin$ and/or a mental illness[2]. 
One of the first institutions in Russia to take care of the mentally ill, the so-called "Dolgaus" (from the German Tollhaus - asylum) was established in Riga in 1786. Riga had become part of the Russian empire in 1721. About two thirds of the patients at the facility suffered from melancholia, there were also epileptics and patients with delusions or aggression[3]. The first psychiatric wards in general hospitals were opened in 1810 and 1819. In 1824, a free-standing mental hospital was also opened in Riga. This was headed up by a well-known physician, Dr. Otto von Huhn (1764-1832)[4]. By the beginning of World War I, there were nine psychiatric hospitals with 1.225 beds in Livland[5]. In addition to state and city psychiatric hospitals, there were also private facilities (the first was opened in 1862 in Riga by Dr.Brutzer), psychiatric wards in general hospitals, a general psychiatric ward in a military hospital (1897), a special department of forensic psychiatry and private asylums for the longterm care of the chronically ill. Special occupational therapy centers were developed for rehabilitation purposes. 112 chronic patients were placed in foster care homes, with financial support from city governments. Patients were treated with the biological and "moral" therapy which was in use at that time.

The first professional psychiatrists appeared in Latvia in the mid-1800s. The first books on psychiatry were published at around the same time. Initially these included statistical reviews of hospital activities, while later they contained papers and monographș devoted to specific psychiatric diagnoses and the history of psychiatry in the region. They contributed their share to the work of various local medical societies, though the first professional society appeared only later, in the 1920s[6].

It would not be an exaggeration to state that the opening of the first university psychiatric clinic at Dorpat in 1881 was an outstanding event. Dorpat, now known as Tartu and located in Estonia, was at that time a provincial city in the territory of Livland. The main city of the territory was Riga. The majority of patients at the university clinic, up to $75 \%$, came from Livland. The chairman of the Department of Psychiatry at that time was a well-known German psychiatrist, Emminghaus. He was succeeded in 1886 by Dr. Emil Kraepelin, who published the second and third editions of his famous textbook during his tenure at Dorpat. Five years later, in 1891, Dr. Kraepelin moved to Heidelberg[7]. He moved not only for scientific and career reasons, but also because of the policy of russification which was being implemented in Livland.

Many Latvian psychiatrists, meanwhile, completed their studies in Dorpat, Moscow, St. Petersburg and Germany. In 1914, the man who would 
become the first Latvian professor of psychiatry, Dr. Hermanis Buduls (1882-1954), defended his doctoral thesis at Dorpat. His research dealt with the racial aspects of psychiatry in the Baltic region[8].

In spite of all these events, until World War I only a relatively small percentage of those who needed psychiatric care could actually receive it. This was the result of two problems. First, care was unevenly distributed, concentrating mostly in large cities. Secondly, psychiatric care was distributed for payment only. For comparison's sake, let us note that the percentage of persons needing psychiatric care who received it in Latvia was between 12 and 33 percent; in England, the percentage was much higher, upwards of 70 percent[9]. Approximately one quarter of beds (303) were free of charge[10] and meant for poor patients. There were also special "doctors of the poor" for outpatients, and charity and sobriety societies were also active[11].

During the years that Latvia was independent, between the first and second world wars, the combined amount of state, municipal and private money made available for psychiatric beds at least doubled. By 1938 the total number of psychiatric beds in Latvia grew to more than 3.000. These were located primarily in five large psychiatric hospitals (four state hospitals and one city hospital). Two of these hospitals were located in Riga, the others were located in Jelgava, Strenči and Daugavpils. However, because there was a lack of any organized system of out-patient clinics, these hospitals were, as before World War I, overcrowded with chronic patients.

There were no boarding houses or "pansionāts"[12] in Latvia until the 1950 s. The average length of stay for inpatients was very high - about 520 days. The rate of turnover in state hospital beds was quite low, at approximately 0.5 per year, compared to a much higher rate of 5.6 in private hospitals where payment was required. The mortality rate remained high, reaching a level of $6 \%$.

Mental health funding was very low (only $1.8 \%$ of the total budget), but the state nevertheless managed to open a large hospital at Dünaburg (Daugavpils) in 1924, as well as a psychiatric ward in one of the largest public hospitals in Riga and another in Jelgava. Of all psychiatric patients treated in Latvia, about $60 \%$ suffered from schizophrenia, some $17 \%$ were manic-depressive, and another 10\% suffered from developmental disorders and syphilitic psychoses[13].

An important event in the development of Latvian psychiątry was the founding of the joint Department of Neurology and Psychiatry within the 
Faculty of Medicine at the University of Latvia (1921), initially chaired by Professor Buduls. The first meeting of the Society of Psychiatrists and Neurologists took place in 1924, and the first textbook about psychiatry, authored by Professor Buduls in two volumes, was published in 1924 and 1929. The majority of scientific publications at the time dealt with some practical aspect of the diagnosis or treatment of medical diseases[14].

The number of psychiatrists in independent Latvia was rather small. In 1929 , for example, there were only nine psychiatrists, or one for every 200.000 residents[15]. However, even in provincial Latvia, psychiatrists worked hard to achieve international standards in the application of modern therapeutics, such as insulin shocks and some types of laboratory serum methods[16].

In 1940, a series of events began which was precipitated by the secret Molotov-Ribbentrop pact between Hitler's Germany and Stalin's Soviet Union. In July, 1940, the Soviet Union annexed Latvia. In 1941, the Nazis occupied the nation. These events proved to be tragic not only for Latvia, but for its psychiatric profession, as well. Soviet psychiatric literature usually emphasizes that between 1940 and 1941, the number of psychiatrists in Latvia grew by $11.5 \%$, a rate five times greater than the rate of growth between 1938 and 1939. It is also emphasizes that all private drugstores and hospitals were nationalized. This was viewed as a necessary step toward the implementation of the Soviet model of psychiatric medicine, which was based on three main principles: full public access, no-cost treatment and preventive medicine[17]. It was one thing to try and implement these idealistic principles of medical care, but one can understand how impossible it was to do this meaningfully in the context of Stalinism. There were massive deportations and executions of innocent people[18,19].

The Nazi occupation of Latvia between two periods of Soviet power also had devastating consequences. Many hospital buildings were destroyed, including large facilities in Jelgava and Daugavpils. At the end of 1945, only $25 \%$ of the hospital beds which had been available in 1940 were still on line. One of the two large hospitals in Riga, the university-affiliated "Sarkankalns", was closed due to an absence of patients. The Nazis had exterminated about 2.000 of them, often together with psychiatrists who insisted on remaining with their patients[20]. As the fascists retreated and the Red Army approached, tens of thousands of people fled Latvia. Among them were many of the nation's best psychiatrists.

Beginning in 1945, Latvia was brought into the Soviet health service system. It used the model of mental health which had been in place in the 


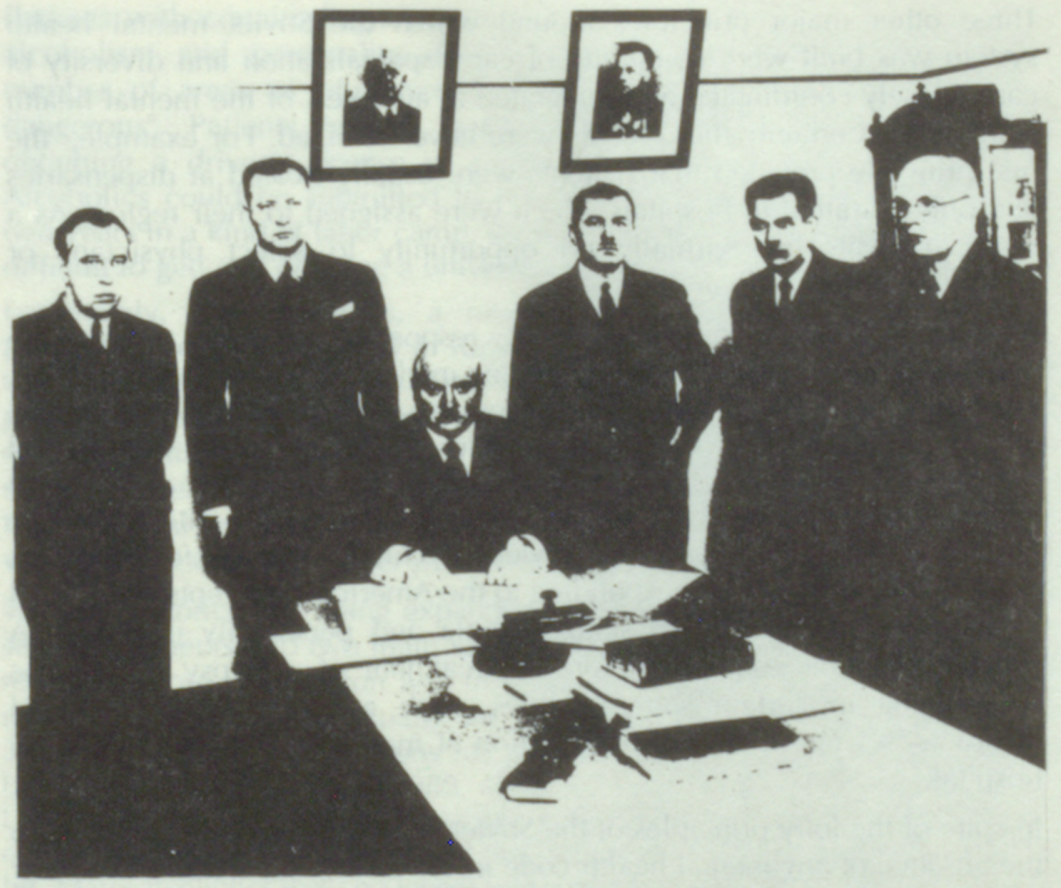

Psychiatrists at the University of Latvia psychiatric hospital.

From left: H.Saltups, N.Jërums, prof.H.Buduls, A.Karps,

P.Pavlovičs, V.Ozoliṇš. December 1937

USSR since the 1930s. This mental health service was public and open to everyone, completely free of charge, planned and oriented toward preventive mental health. There were two basic kinds of institutions in this system: hospitals and dispensaries, a dispensary being rather similar to a single-specialty outpatient clinic. Hospitals and dispensaries were located under one roof or in separate places, and they were often operated by separate administrations. They were, however, interconnected on the basis of geographical area, with teams assigned to specific areas. As a result, most psychiatric hospitals were responsible for specific urban or rural areas. These areas, in turn, were also defined regions for psychiatric dispensaries or, in the case of smaller or more rural areas, individual psychiatric offices. 
Three other major principles around which the Soviet mental health system was built were continuity of care, specialization and diversity of care, closely coordinated and integrated at all levels of the mental health system[21]. Certainly these ideals were never realized. For example, the first principle provided that patients were usually treated at dispensaries and only admitted to hospitals which were assigned to their region. As a result, patients had virtually no opportunity to select physicians or treatment centers of their choice.

As time went on, the system eventually responded somewhat more to the needs of patients, as well as to increasing medical specialization. In 1946, inpatient facilities and dispensaries began to specialize in treating patients of certain age or diagnostic groups. Children's departments, schools and "pansionats", adolescent programs[22], geriatric centers and alcohol and chemical dependency units were developed. Treatment facilities were set up for dealing with what in Soviet psychiatry were referred to as borderline conditions, corresponding to the American concepts of atypical psychoses, milder forms of schizophrenia and personality disorders. A special unit was established for the treatment of epilepsy. Physicians specializing in certain sub-specialties, such as suicidology or sexual disorders, set up offices for consultation at more than one dispensary or hospital.

In spite of the lofty principles of the Soviet health care system, and due to the absence of any mental health code in the USSR, there were a number of developments which led to abuse and violation of patient rights. One unfortunate development was a shift in emphasis from good clinical decision-making to an increased focus on the administrative aspects of health care. It became more important to collect and publish statistics and to make decisions about the mental health system based on considerations of theory or public relations. Genuine concern about the quality of care and the advancement of scientific knowledge often took a back seat to medical bureaucracy.

Probably the best example of such a violation was the introduction of a centralized registry of psychiatric patients. One of the reasons this list was compiled was the perceived need to collect data and statistics. Whether they liked it or not, patients were placed on the list, which was mandated primarily by the need to provide statistical data and information about various diagnoses and intensity of care. There was a special list within the registry of patients who were considered to be "socially dangerous"[23]. The term "socially dangerous" at first referred to mentally ill criminals and violent persons. However, the definition was gradually expanded to include non-violent psychiatric patients who were simply troublesome or a public nuisance. 
Patients with certain diagnoses such as schizophrenia, epilepsy or even alcoholism and personality disorders could face discrimination in a number of areas of life, even if they were not defined as "socially dangerous". Patients on the psychiatric registry would have trouble obtaining a driver's license or receiving permission to travel abroad. Alcoholics could be submitted to compulsory treatment for as much as two years in a kind of labor camp, the LTP|24]. Some jobs would be more difficult to get, and entering a university would become a problem.

Fortunately, by the 1970s, a more flexible attitude concerning the psychiatric registry emerged in Riga. A consultative centre was set up in the Riga Psycho-Neurological Hospital which allowed doctors to evaluate patients and provide high-quality psychiatric care to patients with mainly non-psychotic and milder forms of mental illnesses|25]. Of course the names of these persons were listed in a medical records department, but their medical records were confidential to some extent, and their names were not placed in the larger psychiatric registry.

Today this concept is being expanded, and dispensaries are beginning to separate patients into two main groups: those with more serious disorders requiring close observation and frequent hospitalization, and those with milder conditions who usually do not need to be hospitalized[26]. In addition, the social restrictions for patients with milder conditions were being relaxed. In 1988 and 1989 , about $13 \%$ of all psychiatric patients in Latvia were in the category of people with milder conditions. All persons on the registry who for all practical purposes were healthy were taken off the list. Many alcoholics were no longer required to be listed in the registry.

Outpatient dispensaries were first introduced in Latvia in 1947, and at the end of the Soviet period there were more than 50 facilities. In 1985 there was one self-standing dispensary, along with four dispensaries in the main psychiatric hospitals in Latvia, as well as 26 regional psychiatric offices[27]. One of the positive effects of these developments was that psychiatric care was being brought to where people lived. The radius of services for a psychiatric hospital had been 100 to 120 kilometers at one time. By 1989, it was reduced to 50 or 60 kilometers. Because of a rise in alcoholism, the first dispensary for chemical addictions was opened in Riga in 1977.

The basic functional unit of a psychiatric dispensary consists of a psychiatrist and a medical nurse. The clinical focus includes not only the diagnosis and treatment of mental illness, but also preventive work, patient education, electroencephalography, networking and referral to other health care facilities, and disability examinations. Patients with psychiatric disability are provided with official certificates for temporary sick-leave, good for as long as four months, or five months if the patient has returned to work at least some of the time during the period in question. When the time is up, patients are re-evaluated, at which time 
one of three levels of permanent disability can be declared so that patients can qualify for social security and pension payments. In most cases permanent disability determinations are made on an inpatient basis after a longer and more detailed assessment in accordance with accepted parameters of psychological, social and occupational functioning[28]. Such evaluations, however, have never been as structured as ones like the GAF SCALE, AXIS V or DSM-IV-R.

The typical full-time workload of a dispensary psychiatrist can be quite demanding. The standard in 1989 was four patients per hour for medical reviews and follow-up, and 45 minutes per house call.

Since "perestroika," the main trend has been to develop a wider range of outpatient psychiatric services for a growing number of patients. On January 1, 1989, 52.375 people in Latvia were receiving some kind of psychiatric care. That is a rate of 19,64 per 1.000 people. In terms of diagnosis, the three most common categories, based on the total number of new cases in 1989 (excluding alcoholism) were borderline (non psychopathic) states $(35.1 \%)$, developmental disorders $(31.8 \%)$ and schizophrenia (15.9\%).

In order to meet the needs of the increasing number of patients needing less intensive psychiatric care, 25 small counseling offices were set up in the main regions of Latvia in the 1980s. These counseling offices were staffed by psychiatrists oriented toward outpatient work and psychiatric nurses. Four counseling centres were opened within outpatient hospital in Riga. A major new addition was the establishment of a psychiatric telephone hot-line in 1981. Since "perestroika," it has been staffed around the clock by psychiatrists and psychologists. A local clergyman also was recruited to help staff the hot-line. For the Soviet Union this was nothing short of revolutionary. The hot-line was established in response to the growing number of attempted suicides. Another response to the need for crisis intervention was the establishment of a small, multi-disciplinary counseling centres in one of Riga's larger clinics[29]. And three specialized psychiatric ambulances were put on line in Riga, each staffed by an on-call doctor and a medical nurse. These operated 24 hours a day, seven days a week.

In spite of improvements which were made, the situation in Latvia in the late 1980 s concerning psychiatric care was still far from ideal. Inpatient beds were reduced in Latvia. This is part of an international trend, but the demand for outpatient services for all age groups exceeds the ability to meet all needs. Plans were drawn up to further divide the dispensaries into smaller units. Under this new plan (1989), one district psychiatrist 
would be responsible for 300 - 350 children and adolescents, and 500600 adults. At the end of the Soviet period, psychiatrists were responsible for about four times as many patients. Another plan was to better integrate psychiatric services into the mainstream of general medical services, assigning psychotherapists to non-psychiatric hospitals and clinics.

As a result of the process of decentralization, several private fee-service diagnostic centres were organized which offered the professional services of psychiatrists, psychologists and psychotherapists, but not social workers. It should be explained that in the Soviet Union there has never been any involvement of social workers or sociologists in clinical psychiatry, and they have received no training in psychotherapy. Even psychologists have played a very limited role. Until now psychiatry has almost completely been the domain of psychiatrists, and most treatment has been based on biological models of mental illness.

In the future, more attention will be paid to day treatment and partial hospitalization programs. These programs will be oriented around certain age groups, such as adolescents and geriatric patients, as well as around certain diagnostic groups, such as schizophrenics and persons with development disorders. Only one day treatment center is currently operating in Riga. It handles up to 100 patients. There are another two centers, in Jelgava and Liepāja, as well as one unit which provides overnight support care in Daugavpils. Private, fee-for-service, nongovernmental medical services are only in the earliest stages of development, as is the nation's health insurance system.

In the 1980s, inpatient psychiatric and chemical addiction treatment was available in twelve hospitals[30]. In 1963, a 125-bed hospital, meant mainly for alcoholics, was opened in Lielstraupe. In 1973, a 200-bed unit opened at the Akniste Republican hospital, but in 1975500 beds were opened in Jelgava. A 150-bed rehabilitation hospital was opened in the township of Vainode. More than 600 beds for patients which chemical additions were established at various large factories and enterprises. Hospitals for chronically ill children were opened in Ainaži in 1955 and Viki in 1972. Unfortunately, the increase in the number of beds has corresponded to a reduction in the amount of space per person - a reduction of as much as three square meters (1989) and to a modification of existing facilities. This has led to overcrowding. In some hospitals there are still two or three times as many patients as are intended for the building. Some men's departments have a particularly gloomy appearance, as they are located in old buildings and furnished with bunk beds. Overcrowding both in mens' and womens' wards creates a negative impression. Wards for violent and chronic patients are in especially grim condition. 


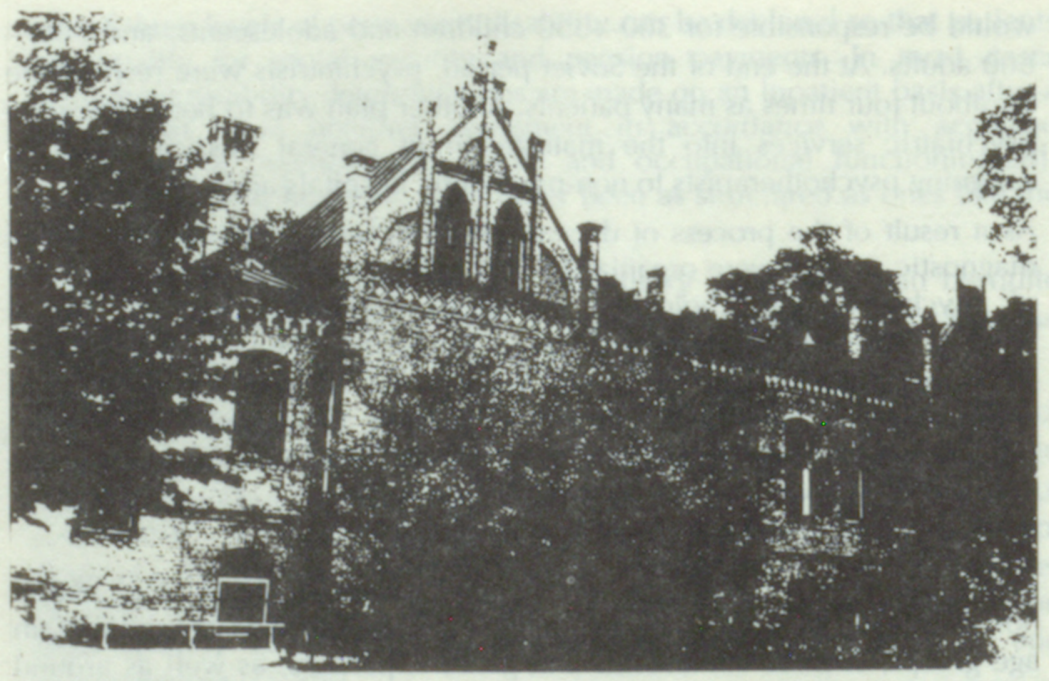

The women's acute care building at the University of Latvia psychiatric hospital "Sarkankalns". 1938

As of January 1,1990, there were 7.125 inpatient beds in Latvia, 1.840 of them situated in units for chemical dependency. In recent years, the number of inpatient beds has been reduced in keeping with the international trend away from inpatient institutional care. On the other hand, Latvia has led the Soviet Union in terms of the number of beds per capita and the number of psychiatrists. In 1989, the number of inpatient beds was reduced by 240 , with 110 of those eliminated at the largest psychiatric hospital in Latvia, the Riga Psycho-Neurological Hospital. Before the reduction, the hospital had 1.500 beds for a total population in the city of Riga of approximately one million.

The reduction in beds was accompanied by a redistribution of the staff workload. If in 1989 a psychiatrist was responsible for 35 patients, by 1990 the number had been reduced to 25. This is fortunate, as it allows doctors to pay more attention to individual patients and improve medical record-keeping. It has also resulted in a more effective use of available hospital space.

Reductions in outlays for inpatient beds has been closely connected to the expansion of outpatient services described above. At the same time, the basic structure of hospital care is undergoing changes. 
For example, a number of departments have been set up which are supposed to be geriatric units, similar to western nursing homes, except that the patient composition has been "diluted" by the addition of chronic psychiatric patients and patients with organic psychoses. In spite of these programs, available bed space has not kept up with the requirements of the population. One fundamental problem which arises when geriatric or crisis units are located in psychiatric institutions is the problem of stigmatization. As is the case in the United States and most other countries, people in Latvia attach a certain sense of shame or stigma to psychiatric treatment, especially if it occurs at a large state hospital.

Because of the stigma attached to psychiatric institutions, geriatric programs have often become shelters for old people who have been left alone or homeless. Unfortunately, the number of special boarding homes (19 in 1985) and adult foster care homes is very small, and therefore persons who need supportive care in a residential setting are often kept in general hospitals or geriatric units, leading to overcrowding[31].

Overall, the trend toward special units based on age or diagnostic groups has had a positive impact on psychiatric hospitals. From the standpoint of statistics, there has been a reduction in the number of new cases per 1.000 , in the average length of stay for inpatients, and in the mortality rate for psychiatric patients. On the other hand, the length of stay remained high for a number of reasons (average 72 in 1985) [32]. There were serious shortages of newer psychiatric medications. Laboratory testing was limited to lithium levels. Serum levels for antidepressants and other psycho tropics were simply not available.

Until the later stages of "perestroika," the mental health budget in Latvia was increased each year to reflect the growing population and an increasing number of patients. Because of budget problems in Latvia in the last few years, however, new services for outpatients, as well as inpatient units for chronic patients, have not kept up with the increasing demand. In many ways psychiatry has not caught up with the level which existed in Latvia in the 1930s. At least at that time it was possible to open a psychiatric unit in a general hospital.

During the period of "perestroika" Latvian psychiatry still suffered from the consequences of the heavy and opposite atmosphere of an all-powerful state system. Over the years all manner of political pressures and slogans were leveled against important areas of psychiatry. Psychoanalysis and modern psychotherapy were denounced as "bourgeois pseudo science". It is curious that the same fate befell behavior therapy, in spite of false respect accorded Ivan Pavlov's neurophysiological research[33]. 


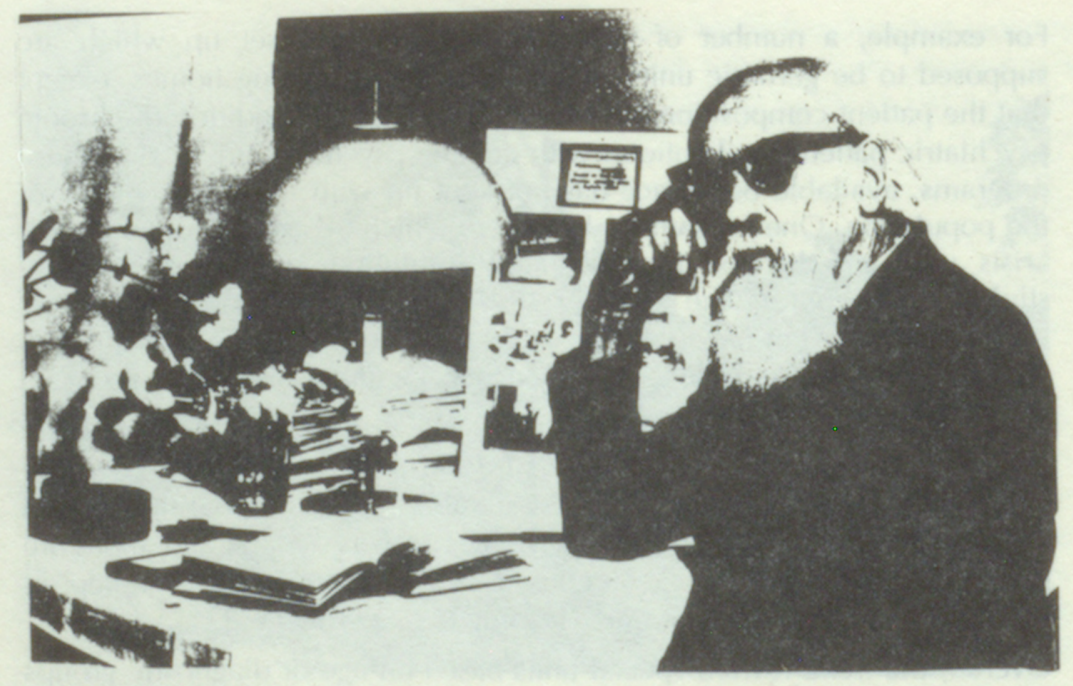

Dr. A.Laksbergs (1901-1983)

The result was a serious deficit or even absence of social workers, medical psychologists and psychotherapists. Specialists in sexual disorders were in short supply because of a sanctimonious and false attitude toward sexual problems. Because of massive denial on the part of official state policy, Latvia experienced shortages of addiction specialists, not only for medical treatment of alcoholism and drug addiction, but also for rehabilitation efforts. Because of political considerations, for years the state denied that substance abuse and drug addiction were major problems.

In spite of much research, scientific papers and decrees, patient rehabilitation in Latvia remained at fairly primitive level. For many years, rehabilitative activities were, as a rule, dull and monotonous, limited to a few types of crafts and assembling of small items.

In 1989, the three most common diagnostic groups in Latvia were alcoholism (38.8\%), schizophrenia (23.6\%) and borderline states $(22.4 \%)$. This brings up the issue of psychiatric diagnosis in Latvia and the USSR. The last system of classification in use in the USSR was an adaptation of the international classification system used by the World Health Organization (ICD-9). However, the adapted Soviet version eliminated whole portions of the ICD-9 on what were termed "matters of principle". The Soviet version claims that many of the states described in the ICD-9 
are not, in fact, psychic in the direct sense of the word. It goes on to state: "There are a number of terms not accepted in domestic [Soviet] psychiatry." And furthermore: "Many terms are not included [in the ICD-9] that are used in domestic psychiatry"|34].

It is difficult to present a serious scientific discussion of the Soviet classification of schizophrenia based on the course of the illness, especially the subtype of schizophrenia termed "mildly pro gradient schizophrenia" or "sluggish schizophrenia." The discussion should focus on the concept itself, with less emphasis on the way in which it was abused politically|35]. It is enough to say that both Kraepelin and Bluer recognized the importance of the course of the illness in making a diagnosis. Kraepelin's classic distinction between dementia praecox and manic-depressive illness was partially based on the clinical course in which schizophrenic patients gradually deteriorated, while bipolar patients generally recovered from episodes of illness and returned to their previous level of functioning. However, the course of illness was overemphasized by Snezhnevsky and his colleagues, who coined such easily abused diagnoses as "sluggish slow pro gradient schizophrenia." Besides, using biological criteria and taking a "pathocentric" (oriented toward pathology) position regarding fragile and socially oriented norms of behavior and sanity, they could hardly escape the temptation to reduce "boundary" (mild) psychic disorders and special personality features to hidden, abortive and mild forms of schizophrenia.

The concept of sluggish schizophrenia within the relatively broad diagnostic criteria of the USSR was generally misused as the diagnosis of choice for labeling political and religious dissidents and other undesirables when the state was looking for a convenient way to remove them from the public eye. This kind of psychiatric abuse by Soviet authorities is well known in the West.

This sad union of political totalitarianism and psychiatric expansionism took on the most odious forms: mandatory registration; "emergency" hospitalization (carried out, as a rule, by ambulance crews and members of the militia) as a means of social and political isolation; forced detention on an inpatient basis; denial of contact with friends and relatives; frequent denial of requests for walks outside the building on grounds of "riotous conduct"; the forced use of medications, and even EST, as a form of punishment or "ideological reeducation"; physical punishment in cases of insubordination; and use of a diagnostic label as a pretext for invoking a legal determination that a person had no control over his behavior.

These abuses of and by psychiatry could only exist with the support of the Soviet psychiatric system itself and certain representatives of the system in 
particular. But the real basis was the Soviet system of criminal law and the principles involved therein. It is very important to know that both the system of criminal law and the system of forensic psychiatry underwent fundamental changes as a result of "perestroika". The infamous Statute 183, and especially Article 65 of the Soviet Latvian penal code (190.1 and 70 , respectively, in the penal code of Soviet Russia), were abolished. These statutes dealt with so-called "anti-Soviet agitation", "propaganda" and "slander against the Soviet regime"[36].

Certainly it would be preposterous to reduce all the diverse scientific activities of Latvian psychiatrists to the ideological and political arguments of Soviet times. Among the many examples of original research performed on a clinical basis at the Riga Hospital (headed by Dr. Zuzanna Sočneva from 1951-1992) were studies on the epidemiological and clinical aspects of schizophrenia, epilepsy, affective and organic disorders, on suicidal behavior and on forensic aspects of developmental disorders[37]. This research was guided and monitored not only by such leading Latvian psychiatrists as Prof. Mintauts Caune (head of the Department of Psychiatry in the Riga Medical Institute) and Prof. Imants Eglitis (a student of A. Snezhnevsky), but also by outstanding scientists from Moscow, Leningrad and Tartu. Among them, to name only a few, were G.J.Rotstein (who took the Chair of Psychiatry in Riga from 1960 to 1969), E.J.Sterenberg, A.G.Ambrumova, M.M.Kabanov (a leading authority in gerontology, suicidology and rehabilitation) and J.Saarma.

The Riga hospital was an educational base both for the Department of Psychiatry and the Faculty for Advanced Learning (headed by Prof. Eglitis) at the Riga Medical Institute, and for Riga's schools of nursing. Postgraduate training often took place at the best Soviet metropolitan educational psychiatric centers, and their top specialists regularly visited Latvia to teach courses and offer counseling. The Scientific Medical Society of Neurologists, Psychiatrists and Neurosurgeons of the Latvian SSR, active since 1947, included six professional divisions with 524 members in 1985[38]. From 1982 to 1989 , almost 60 years after Buduls' textbook, a second Latvian language book, in two parts, was published by Prof. Eglitis[39]. It is worthwhile to mention the scientific activities of non-metropolitan Latvian specialists working on a clinical basis at such places as the Jelgava Psychiatric Hospital, which had a large inpatient children's unit. In 1987, a museum of the history of psychiatry was opened at the Jelgava Hospital in commemoration of the centenary of the hospital[40]. Proceedings of various scientific congresses and conferences held in Latvia were published, but a magazine devoted specifically to Latvian psychiatry never existed. 
The fall of the Soviet empire of which Latvia was an integral part for more than half a century brought an air of freedom and national revival, but also a state of economical, social and political autonomy which is currently being shared by many post-communist states. Contemporary Latvian psychiatry faces major challenges in dealing with financial privation, a lack of medication, an outdated system of psychiatric facilities, shortages in all categories of mental health professionals, a decline in the quantity of original research, crises in educational and counseling programs, deficits in psychiatric strategies and concepts, and almost non-existent ethical standards.

Although some of these ailments cannot be treated without generous help from western colleagues, it is primarily the task of Latvian psychiatrists themselves to overcome this difficult historic crisis. On the way to the objective of building a democratic system in Latvia, the mental health profession will bear an extraordinary responsibility.

\section{REFERENCES}

1. Сочнева 3.Г. Основные этапы развития психиатрической помощи в Латвии и ее дальнейшие перспективы: Докторская диссертация /машинописы/. - Ленинград, 1973.

2. Бупацель $П$. Самоубийство с древнейших времен до наших дней. -2 -е изд. - СПБ, 1900. - 67 с

3. Федототов ДД. Очерки по исстории отөчественной психиатрии: Т.1. - Москва, 1957. - 104 с.

4. Сочнева 3.Г. Рижской респубпиканской психиатрической бопьнице 150 пет // Психиатрия, невропатопогия и нейрохирургия. - Рига, 1974 - 4.1. - С. 5-23.

5. Лифпяндская губерния // Новый энцикпопедический споварь:Т.24. - Петроград, 1914. - С.713.

6. Сочнева 3.Г. Основные этапы развития психиатрической помоци в Латвии и еө дальнейшие перспективы: Докторская диссертация (машинопись). - Ленинград .1973. - С.5-47.

7. Хазанов А.Н. Эмипь Крепепин и его профессорство в Дерптском университетө // Психиатрия, невропатопогия и нейрохирургия. - Рига, 1974. - 4.1. - С.204-208.

8. Будуп Г. М. К сравнитепьной рассовой психиатрии. - Юрьев, 1914. -220 с

9. Сочнева 3.Г. Ор.cit., p.30.

10. Озопиньш 8. Социальный состав бопьных, призреваемых в. психиатрических учреждениях Прибалтийских губерний в 19 в. // III Респубпиканская конференция невропатопогов и психиатров Латвийской ССР. - Рига, 1965. - С. 171

11. Сочнева 3. . Op. cit., p.30.

12. A pansionat is a large facility of $50-450$ beds, similar to a nursing home, but specifically for chronic and elderly psychiatric patients, children with severe developmental disorders.

13. Сочнева 3.Г.- Op.cit., p.53-69

14. Эгпитис И.Р. Херманис Будупис ( 1882-1954) // Из истории медицины. - 1990. - Т.19. С. $140-145$.

15. Сочнева 3.Г. - Op. cit., p.53-69.

16. Эглитис И.Р. Музей истории бопьницы // Из истории медицины. - 1990. - Т.19. - С.186-189.

17. Сочнева 3.Г. - Op. cit., p.70-73

18. Kiršentåls O. Latvijas iedzivotăju deprimăcija // Medicina. Vēsture. Valoda - Riga, 1993. - 39. - 40.lpp.

19. Левицкий Д.А. Национальность жертв несушественна для коммунистической впасти. /I Родник. - Рига, 1990. - N93. - C. 52-57

20. Сочнева 3.Г. Op. cit., p. $73-74$ 
21. Воронков Г.Л., Видренко А.Е., Шевчук И.Д. Практический справочник врача - психиатра. - Киев: Здоров'я, 1990. - С.7.

22. Zalcmanis J. leskats bê̆rnu psihiatrijas vêsturē Latvijă // Medicina. Vẽsture. Valoda. - Riga, 1993 - 30-36. Ipp

23. Котов В. Некоторые принципы отбора бопьных в группы специального диспансерного учета // Актуапьные вопросы невропатопогии, психиатрии и нейрохирургии. Тезисы докладов /I сьезда невропатопогов, психиатров и нейрохирургов Латвийской ССР. - Рига. 1985. - T.1. - C.32-34

24. LTP is Russian abbreviation for "leCebno-trudovoj profilaktorij", a linguistical monster, that can be roughly translated as Labor Treatment Preventive Center.

25. Сочнева 3.Г. Лиепиньш Ю.К. Состояние и перспективы развития психиатрической помощи в Латвийской ССР // Актуальные вопросы невропатопогии, психиатрии и нейрохирургии. Тезисы докпадов \|| сьезда невропатопогов, психиатров и нейрохирургов Латвийской ССР - Pига, 1985. - Т.1. - С.32-34.

26. Here and further all figures since 1986 are taken from unpublished Annual statistics of Latvian Ministry of Health.

27. Сочнева 3.Г., Лиепиньш Ю.К. Ор.cit.

28. Воронков Г.Л., Видренко А.Е., Шевчук И.Д. Практический справочник врача-психиатра. Киев: Здоров'я, 1900. - С.89-102.

29. Когда бопит душа.. // Советская Моподежь. - 1989. - 9. сент.

30. Сочнева 3.Г., Лиепиньш Ю.К. Ор. cit.

31. Сочнева 3.Г., Лиепиньш Ю.К. Ор. cit

32. Зак Л.К. Психоневропогические пансионаты Латвийской ССР // Актуальные вопросы невропатопогии, психиатрии и нейрохирургии. Тезисы докладов II съезда невропатопогов, психиатров и нейрохирургов Латвийской ССР. - Рига, 1985 - Т.1. - С. 17-21.

33. Сочнева 3.Г., Лиепиньш Ю.К. Ор. cit.

34. Костандов E.A. Обьединенная сессия двух акаремий в истории отечественной психиатрии // Журнал невропатопогии и психиатрии им. Корсакова - 1990. - №12 - С.74-77.

35. Психические расстройства (раздеп $\mathrm{V}$ международной статистической кпассификации бопезней, травм и причин смерти 9-го пересмотра, адалтированный для испопьзования в СССР) - Москва, 1982, - C.5-6.

36. Probes L., Kuznecovs V., Verbitski V., Molodyi V. The Final Years of Soviet Psychiatry. (In print)

37. Подрабинек А. Каратепьная медицина. - Нью-Йорк, 1973.

38. Сочнева 3.Г. Работа научного медицинского общества невропатопогов, психиатров и нейрохирургов Латвийской ССР в 1979-1985r.r. // Актуальные вопросы невропатопогии, психиатрии и нейрохирургии. Тезисы докладов II сьезда невропатопогов, психиатров и нейрохирургов Латвийской ССР. - Рига, 1985. - Т.1. - С. 5-7.

39. Eglitis I. Psihiatrija - Riga: Zvaigzne, 1989; Vispấrêjā psihopatologija - Riga: Zvaigzne, 1982.

40. Эглитис И.Р. Музей истории бопьницы // Из истории мерицины. - 1990. - Т.19. - С. 186-189.

\section{Dr. med. Vladimirs KUZNEECOVS}

Rigas psihoneiroloǵiskã slimnica

Tvaika iela 2

Riga LV 1005

Latvija 